\title{
Molecular Dissection of the Interaction between hBLT2 and the G Protein Alpha Subunits
}

\author{
Krishna Moorthy Vukoti, Won-Kyu Lee, ${ }^{a}$ Ho-Jun Kim, ${ }^{;}$Ick Young Kim, ${ }^{\ddagger}$ \\ Eun Gyeong Yang, Cheolju Lee, and Yeon Gyu Yu ${ }^{\dagger *}$ \\ Life Sciences Division, Korea Institute of Science and Technologv, P.O. Bor 131, Cheongrvang, Seoul 130-650, Korea \\ ${ }^{\dagger}$ Department of Chemistry, Kookmin Lnversity, Seoul 136-702, Korea. ${ }^{*}$ E-mail: . \\ ${ }^{\ddagger}$ Division of Biotechnologv and Genetic Engineering, College of Life and Enironmental Sciences, Korea Chiversity: \\ Seoul 136-701, Korea \\ Received April 23, 2007
}

\begin{abstract}
Leukotriene B4 (LTB4) is a potent chemoattractant for leukocytes and considered to be an inflammatory mediator. Human BLT2 (lBLT2) is a low-affinity G-protein coupled receptor for LTB4 and mediates pertussis toxin-sensitive chemotactic cell movement. Here. we dissected the interaction between lBBLT2 and G-protein alpha subunits using GST fusion proteins containing intracellular regions of $\mathrm{hBLT} 2$ and various $\mathrm{G} \alpha$ protein including $\mathrm{G} \alpha \mathrm{il}, \mathrm{G} \alpha \mathrm{i} 2, \mathrm{G} \alpha \mathrm{i}, \mathrm{G} \alpha \mathrm{sl}, \mathrm{G} \propto 0 \mathrm{l}$. and $\mathrm{G} \alpha z$. Among the tested $\mathrm{G} \alpha$ subunits. $\mathrm{G} \alpha \mathrm{i}$ s showed the highest binding to the third intracellular loop region of $\mathrm{hBLT} 2$ with a dissociation constant $\left(\mathrm{K}_{\mathrm{L}}\right)$ of $5.0 \times 10^{-6}$ $\mathrm{M}$. These results suggest that $\mathrm{G} \alpha \mathrm{i} 3$ has the highest affinity to $\mathrm{hBLT} 2$. and the third intracellular loop region of hBLT2 is the major component for the interaction with $\mathrm{G} a \mathrm{~s}$.
\end{abstract}

Key Words : Leukotriene B4, hBLT2, G-protein, Intracellular loop, GPCR-G protein interaction

\section{Introduction}

Leukotriene B4 $\left(\mathrm{LTB}_{4}\right)$. generated from arachidonic acid via the 5-lipoxygenase pathway is a lipid inflammatory mediator of the recruitment and activation of leukocytes. ${ }^{1}$ It exhibits strong chemotactic effects on neutrophils ${ }^{2}$ as well as eosinophils. ${ }^{3.4}$ Although LTB4-mediated leukocyte recruitment has a protective role against various pathogens. ${ }^{5.6}$ it is also involved in multiple inflanmmatory pathologic conditions. including rheumatoid arthritis. ${ }^{7}$ astluma. ${ }^{8}$ and inflammatory bowel disease. ${ }^{9}$ Leukotriene-deficient mice are deficient in their response to inflammatory stimuli. ${ }^{16}$ Therefore. antagonists for LTB4 receptors are in development for therapeutic purposes. ${ }^{11-13}$ LTB4 mediates its function through G-protein coupled receptors (GPCR). There are two human GPCRs for LTB4 (hBLT1 and hBLT2) which have strong sequence homology ( $45.2 \%$ amino acid identity) with each other and the corresponding mouse genes. ${ }^{1+15}$

Human BLT2 is a low-affinity LTB4 receptor. which has an approximately 100 -fold lower affinity $\left(\mathrm{K}_{\mathrm{D}}=20 \mathrm{nM}\right)$ than that of $\mathrm{hBLT} 1\left(\mathrm{~K}_{\mathrm{D}}=0.22 \mathrm{nM}\right) \cdot{ }^{16}$ It possesses pharmacologically different properties than hBLTl since a number of hBLTl antagonists do not inhibit LTB4 binding to hBLT2. ${ }^{17}$ Moreover. hBLT2 is expressed relatively ubiquitously in human tissues ${ }^{16}$ whereas hBLTl is expressed predominantly in leukocytes. ${ }^{18}$ suggesting that hBLT2 mediates cellular functions in tissues other than leukocytes. In addition. hBLT2 is implicated in the cell transformation or oncogenic pathway. The expression of hBLT 2 is enhanced in transformed cells by oncogenic Ha-Ras. ${ }^{15}$ and LY293111, an

$\overline{{ }^{a} \text { Krishna Moorthy Vukoti and Won-Kyu Lee are equally contributed in }}$ this work antagonist of hBLT2. inhibits the proliferation of human pancreatic cancer cells. ${ }^{30}$ Hence. blockade of LTB4/hBLT2 and the downstream signaling pathway is assumed to be a potential target for the treatment of cancer as well as inflanmmatory disease.

The signaling pathway of hBLT2 was investigated by measuring the cellular levels of cAMP or $\mathrm{Ca}^{-2}$ in CHO cells expressing hBLT2 ${ }^{16}$ The effect of LTB4 on the transformed CHO cells with hBLT2 exhibited increased intracellular calcium concentration as well as induced chemotactic responses. indicating that lBBLT2 is coupled to both the $\mathrm{Gi}$ and $\mathrm{Gq}$ families of $\mathrm{G}$-proteins. When the cells were pretreated with pertussis toxin (PT). the chemotactic response of the hBLT2-transformed cells by LTB4 was completely blocked, indicating that a member of the Gi family mediates the chemotactic responses. In contrast. the increase of intracellular calcium by LTB4 in hBLT2-transformed cells was only partially blocked by treatment with PT. suggesting that the calcium response was mediated both by PT-sensitive and PT-insensitive G proteins or hBLT2 couples to different types of G-proteins. In the case of hBLTl, its signaling pathway could be mediated by various types of $\mathrm{G}$ proteins. Activation of hBLTl by LTB4 inhibits the formation of cAMP through PT-sensitive G-proteins. ${ }^{21}$ and cotransfection of hBLT1 with $\mathrm{G} \alpha 16$ in Cos-7 cells results in an enhanced production of inositol phosphate in response to LTB4."2 suggesting that the LTB4-dependent activation of phospholipase $\mathrm{C}$ involves $\mathrm{Gl} 6$ in addition to $\mathrm{Gi}$. Although $\mathrm{hBLTl}$ and hBLT2 have been coupled with more than two types of $G$ proteins. as yet the specificity of hBLT1 and hBLT2 to various $\mathrm{G}$ proteins has not been completely analyzed. Also. the PT-sensitive Gi protein(s) responsible for hBLT2mediated chemotaxis has yet to be uncovered. 
In this study. we prepared various $\mathrm{G} \alpha$ subunits and GST fusion proteins containing intracellular regions of hBLT2. and investigated the relative affinities of the GST fusion proteins to the $\mathrm{G} \alpha$ subunits of the Gi family (Gil. Gi2. Gi3. Gol. or $\mathrm{Gz}$ ) as well as $\mathrm{Gsl}$ to identify the $\mathrm{Gi}$ protein(s) critical for hBLT2-mediated chemotactic mobility. We showed that the third intracellular loop region of hBLT2 is the critical region for the interaction with the $\mathrm{G} \alpha \mathrm{i} 3$ protein by characterization of the interaction between and $\mathrm{G} \alpha \mathrm{i} 3$ and GST fusion proteins.

\section{Materials and Methods}

Construction of expression vectors for GST fusion proteins and the $\mathbf{G} \alpha$ subunits. The oligonucleotides encoding the second intracellular region (iL2. anino acids 118 $1+1$ ) and the third intracellular region (iL 3 . amino acids 206 225) of hBLT2 were ligated at the C-terminus of GST in pET22b to produce pGST-iL2 $2_{\text {BLT: }}$ and pGST-iL3 $3_{\text {BLT:. Also. }}$ the C-terminus tail of hBLT2 (CT, amino acids 287-358) was amplified from pcDNA3-hBLT2 harboring the cDNA of hBLT2 (Gene bank accession number: AB029892), and ligated at the C-terminus of GST in pET22b to produce

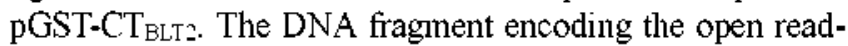
ing frame of the human $\mathrm{G} \alpha \mathrm{i} 3$ was amplified by $\mathrm{PCR}$ from human fetal liver cDNA (Novagen, USA), and the clones $\mathrm{G} \alpha$ il, $\mathrm{G} \alpha \mathrm{i} 2 . \mathrm{G} \alpha o \mathrm{l}, \mathrm{G} a \mathrm{~s} 1$ and $\mathrm{G} \alpha \mathrm{z}$ were obtained from the Human Gene Bank (Korea Research Institute of Bioscience and Biotechnology. Korea). The genes coding G $\alpha$ il, G $\propto$ i2. $\mathrm{G} \alpha \mathrm{i}_{3}, \mathrm{G} 00 \mathrm{l}$ and $\mathrm{G} \propto \mathrm{z}$ were amplified with specific primers and cloned into a pET28a vector to produce $\mathrm{G} \alpha$ proteins contain a $6 \mathrm{X}$-His tag at the N-terminus.

Preparation of GST fusion proteins and the G $\alpha$ subunits labeled with a fluorescence probe. GST, GST-iL2 BLT: $_{2}$ GST-iL3 ${ }_{\mathrm{BLT}}$, and GST-CT $\mathrm{BLT}$, were expressed in $E$. coli BL2l(DE3) cells. The expression of GST or GST-fusion proteins were induced by the addition of $1 \mathrm{mM}$ of IPTG when the optical density of culture at $600 \mathrm{~nm}$ reached 0.7 . and cells were harvested after $4 \mathrm{hr}$ of growth at $37^{\circ} \mathrm{C}$. The harvested cells were disnupted by ultrasonication in $25 \mathrm{~mL}$ buffer A ( $50 \mathrm{mM}$ sodium phosphate. $0.15 \mathrm{M} \mathrm{NaCl}$. pH 7.4. and $1 \mathrm{mM}$ PMSF and $1 \mathrm{mM}$ EDTA) with $80 \mathrm{mg}$ of Complete Mini Cocktail inhibitor (Roche Diagnostics. Germany). The ly'sate was centrifuged at $13.000 \mathrm{rpm}$ and the supernatant was loaded onto a glutathione affinity resin columun (Peptron Inc. Korea), which was pre-equilibrated with buffer A. After washing thoroughly. the GST fused proteins were eluted using $20 \mathrm{mM}$ reduced glutathione in buffer A. The glutathione in the purified protein sample was removed by desalting column and it was stored at $-80{ }^{\circ} \mathrm{C}$ for further analysis. The purified GST fusion proteins were dialyzed against buffer $\mathrm{A}$ and stored at $-80^{\circ} \mathrm{C}$.

The N-terminus histidine tagged $\mathrm{G} \alpha$ (sl. il. i2. i3. ol and z) proteins which were expressed in $E$. coli Rosetta 2 (DE3). Purification of His-tagged $\mathrm{G} \alpha$ proteins was performed as described previously. ${ }^{23}$ Briefly, expression of these proteins was induced by the addition of $1 \mathrm{mM}$ of IPTG when the optical density of the culture at $600 \mathrm{~mm}$ reached 0.7 , and cells were harvested after $16 \mathrm{hr}$ of growth at $18^{\circ} \mathrm{C}$. except for $\mathrm{G} c z$. which was expressed at 24 hr at $12{ }^{\circ} \mathrm{C}$. All the $\mathrm{G} \alpha$ proteins, except $\mathrm{G} \alpha$. were at least $30-40 \%$ in the soluble form. Less than $5 \%$ of the expressed $\mathrm{G} \propto x$ protein was recovered as soluble protein. The cells were lysed by ultrasonication in $25 \mathrm{~mL}$ buffer $\mathrm{C}(50 \mathrm{mM}$ Tris-HCl. $0.15 \mathrm{M}$ $\mathrm{NaCl}, 20 \mathrm{mM} \beta$-mercaptoethanol and $1 \mathrm{mM}$ PMSF. pH 7.4) and centrifuged at $13,000 \mathrm{rpm}$ to remove the cell debris and insoluble proteins. The cleared lysates were loaded onto a $\mathrm{Ni}^{2-}$-charged chelating colunn pre-equilibrated with buffer C. The His-tag labeled $\mathrm{G} \alpha$ proteins were eluted with $0.3 \mathrm{M}$ imidazole in buffer $A$ and labeled with a fluorescence probe according to the manufacturer's manual (Sigma) using flourescein isothiocyanate (FITC).

Measurement of the interaction between GST fusion proteins and the $\mathrm{G} \alpha$ subunits. The interaction of GST, GST-iL2. GST-iL3, GST-CT with FITC-G $\alpha$ proteins were analyzed by measuring the amount of bound $\mathrm{G} \alpha$ protein on immobilized GST fusion proteins. GST or GST fusion proteins $(0.5 \mu \mathrm{g})$ in $100 \mu \mathrm{L}$ were attached to a glutathione plate (BD Biosciences, USA) by incubation at room temperature for $1 \mathrm{hr}$, followed by incubation with $5 \%$ (w/v) skim milk in PBS-T ovemight at $4{ }^{\circ} \mathrm{C}$. After washing the plate six times with PBS-T, the plate was incubated with FITC-labeled $\mathrm{G} \alpha$ protein $(100 \mu \mathrm{L} /$ well $)$ in buffer $\mathrm{B}$ for $\mathrm{I}$ lur at room temperature. The amount of bound FITC-labeled $\mathrm{G} \alpha$ protein was eluted into solution by incubation with $100 \mu \mathrm{L}$ of $8 \mathrm{M}$ urea solution for $15 \mathrm{~min}$. The intensity of fluorescence in the solution was measured at the excitation wavelength of 495 $\mathrm{nm}$ and at the emission wavelength of $525 \mathrm{~nm}$ using a TRIAD microplate reader (Dynex Technologies. USA). The fluorescence intensity from each $\mathrm{G} \alpha$ protein bound to immobilized GST was subtracted from the intensity from $\mathrm{G} \alpha$ proteins bound to specific GST-fusion proteins. Alternatively. the interaction between GCA3 and GST-iL3 $3_{\text {BLT }}$ was measured by enzyme linked immunosorbent assay (ELISA) using unlabeled Gci3. After binding GST-iL3.LT $(0.5 \mu \mathrm{g})$ onto a glutathione plate. serially diluted $\mathrm{G} \propto \mathrm{i} 3$ was added. The plate was incubated ( $100 \mu \mathrm{L} / \mathrm{well})$ for $90 \mathrm{~min}$ at room temperature. and washed 6 times ( $300 \mu \mathrm{L} / \mathrm{wvell}$ ) with PBS-T to remove unbound proteins. The complex was incubated for 1 lor with $100 \mu \mathrm{L}$ of anti-His tag antibody (1:3000, Sigma) and for 1 lur with HRP-conjugated anti-rabbit IgG (1:3000. Sigma). The plate was washed 6-times with PBS-T. and 100 $\mathrm{ml}$ of OPD $(\mathrm{l} \mathrm{mg} / \mathrm{mL})$ in $1 \mathrm{X}$ stable peroxide substrate buffer (Pierce) was added. The reaction was terminated by the addition of $100 \mu \mathrm{L}$ of $2.5 \mathrm{M}$ sulfuric acid, and the absorbance at $490 \mathrm{~nm}$ was measured using a TRIAD microplate reader (Dỵnex Technologies. USA).

\section{Results}

Preparation of GST fusion proteins and various $\mathbf{G} \alpha$ subunits. To characterize the interaction mode of hBLT2 with various $\mathrm{G} \alpha$ proteins. GST-fusion proteins containing the intracellular loop regions of hBLT2 were designed as 
(A)

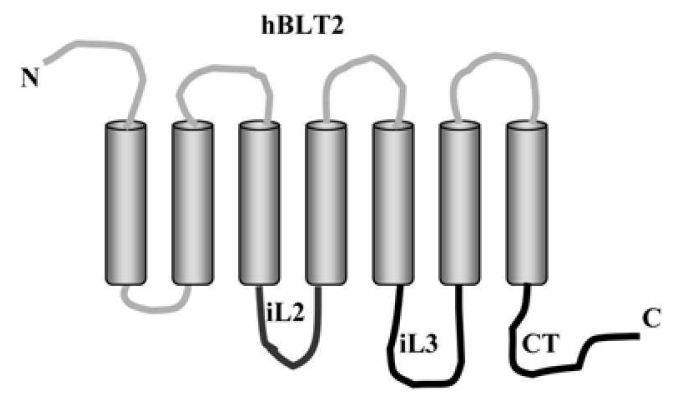

(B)

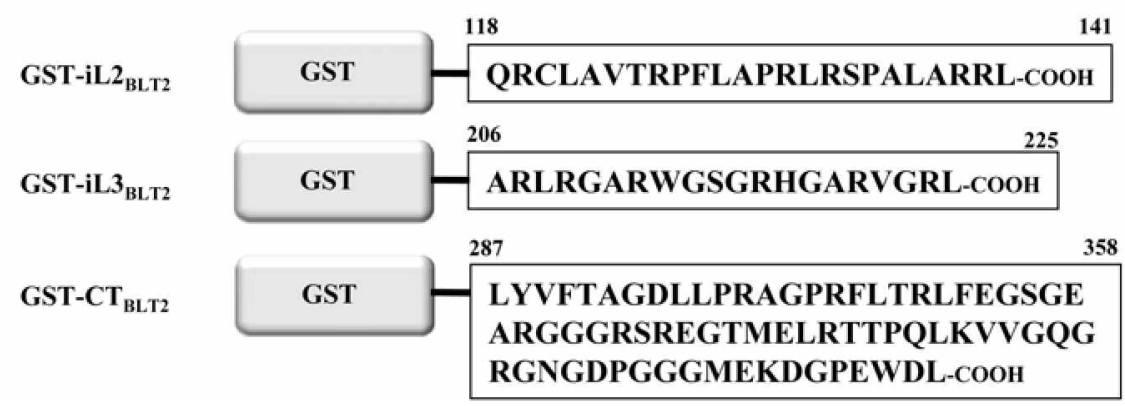

Figure 1. Schematic representation of GST fusion protein of the intracellular domains of $h_{B L T}$. (A) The transmembrane helixes of $h B L T 2$ were indicated as cylinders, and $i L 2$, iL 3 and $C T$ regions were indicated as thick black lines. along with the residue numbers at the $N$ - and $C$ tenminus of each region. (B) The GST-fusion proteins contaned iL2, iL 3 and CT at the C-tenminus of glutathione S-transferase (GST). The residue numbers of iL 2, iL 3 and $C T$ are indicated at the $\mathrm{N}$ - and $\mathrm{C}$-temninus of each region.

(A)

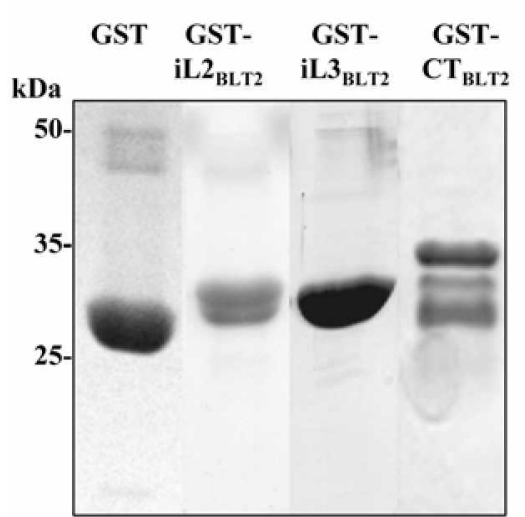

(B)

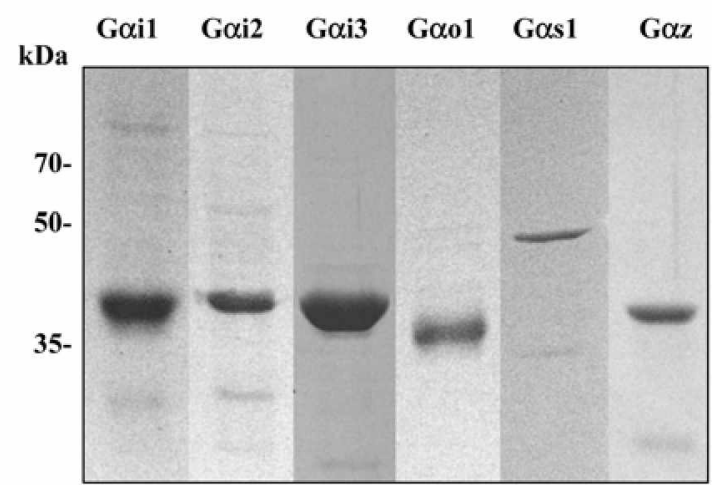

Figure 2. Purification of GST-iL2 $2_{\mathrm{BLT}}$ GST-iL3 $3_{\mathrm{BLT}}$, GST-CT $\mathrm{BLT}_{2}$ and G $\alpha$ proteins. (A) SDS-PAGE of purified GST, GST-iL2 $\mathrm{BLT}$, GSTiL $3_{\mathrm{BLT} 2}$, and GST-CT $\mathrm{BLT}_{2}$ (B) SDS-PAGE of purified $\mathrm{G} \alpha$ proteins.

depicted in Figure 1, and expression vectors for these GST fusion proteins and various $\mathrm{G} \alpha$ proteins were constructed. The GST-fusion proteins containing the second intracellular loop (iL2). the third (iL3) intracellular loop or the Cterminal tail (CT) of hBLT2 at the C-teminus of GST was also expressed in $E$. coli as soluble proteins. These fusion proteins (GST-iL2 $2_{\mathrm{BLT}}$. GST-iL3 BLTs, and GST-CT $_{\text {BLT2) were }}$ purified semi-homogeneity and the molecular weights of the purified GST-iL2 2 BLT2. GST-iL $3_{\mathrm{BLT}}$, and GST-CT determined to be $29.4,30$ and $34.4 \mathrm{kDa}$. respectively (Fig. 2A). The recombinant $\mathrm{G} \alpha \mathrm{L} \mathrm{L}$. Goil. $\mathrm{G} \alpha \mathrm{i} 2 \mathrm{G} \alpha \mathrm{s}$. $\mathrm{G} \alpha \mathrm{l}$, and $\mathrm{G} \alpha \mathrm{z}$ were purified to homogeneity using an ion exchange and $\mathrm{Ni}^{3-}$-affinty column (Fig.2B). Approximately 20
$-30 \%$ of the bacterially expressed $\mathrm{G} \propto \mathrm{A} \mathrm{l} . \mathrm{G} \propto \mathrm{\alpha} 2$ and $\mathrm{G} \propto \mathrm{O}$ were recovered as soluble protein (data not shown) and a minimum of $2 \mathrm{mg}$ of purified protein were obtained from 1 $\mathrm{L}$ cultures. Most of the expressed $\mathrm{G} c \mathrm{~A} 3$ was expressed as soluble protein. and $10 \mathrm{mg}$ of purified protein was obtained from $1 \mathrm{~L}$ culture. The Gasl was purified as described previously ${ }^{23}$ In the case of $\mathrm{G} \alpha \mathrm{z}$, only about $5 \%$ was recovered as a soluble fraction and the yield was $0.5 \mathrm{mg}$ of purified protein per $1 \mathrm{~L}$ culture. All the purified $\mathrm{G} \alpha$ subunits were labeled with FITC and the average molar ratio of fluorescence label to $\mathrm{G} \alpha$ proteins was 1.5 to 2.0 , based on the fluorescence intensities relative to the protein concentrations. 


\section{(A)}

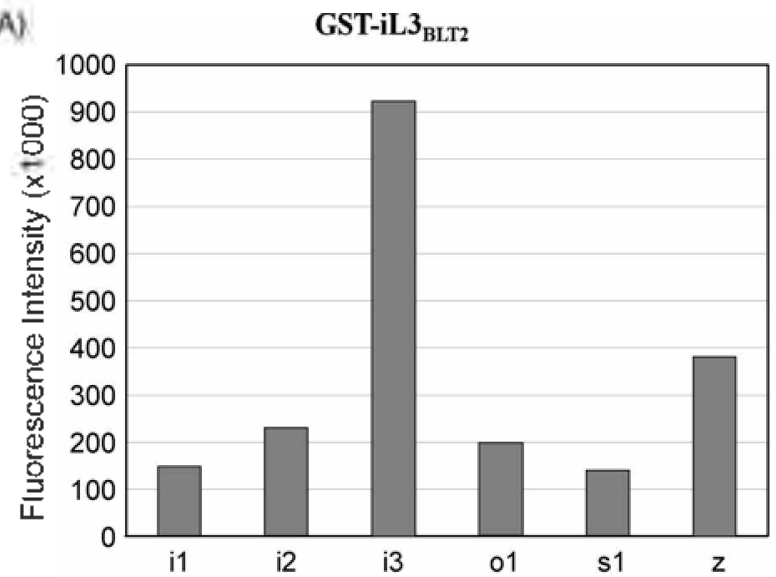

(B)

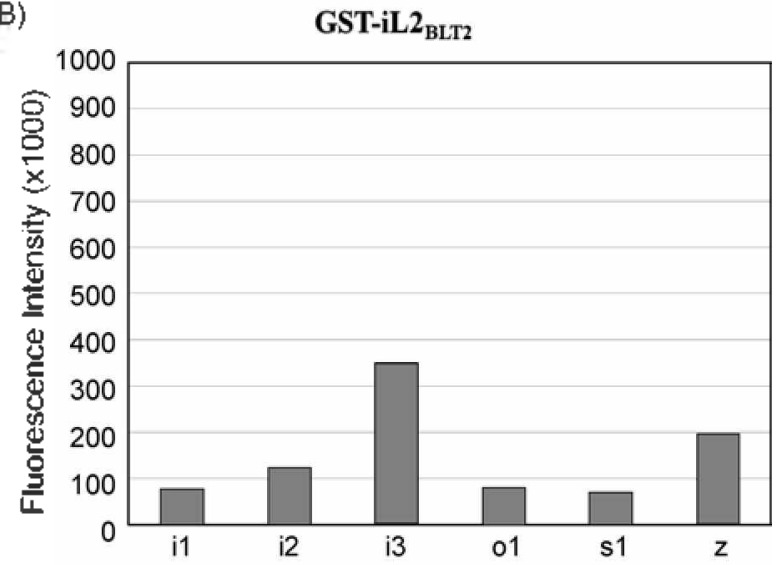

(C)

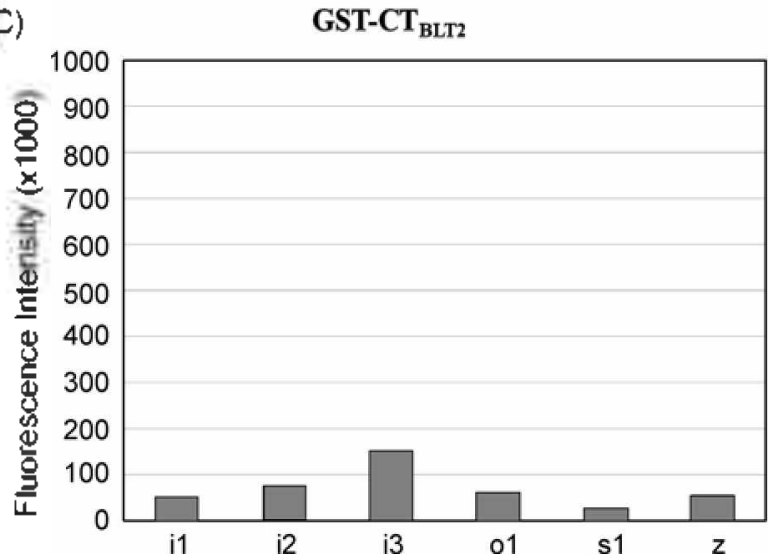

Figure 3. Specific interaction between intracellular regions of lıLL2 and G $\alpha$ proteins. Puritied GST-iL $\hat{B}_{\mathrm{BLT}}(\mathrm{A})$, GST-iL $2_{\mathrm{BLT} 2}$ (B), or GST-CT $\mathrm{BLT}_{2}$ (C) were immobilized, and the intensities of fluorescence from the bound FITC-labeled Goil (il), Goi2 (i2), $\mathrm{G} \alpha{ }_{3}(\mathrm{i}), \mathrm{G} \alpha 0 \mathrm{l}(0 \mathrm{l}), \mathrm{G} \alpha \mathrm{s} \mathrm{l}(\mathrm{sl})$ and $\mathrm{G} \alpha z$ (z) were measured.

The iL3 region of hBLT2 and $\mathrm{G} c \mathrm{i} 3$ are major determinants for the interaction of hBLT2 with G-protein. The involvement of $\mathrm{Gi}$ has been implicated in the signaling pathway of hBLT $2{ }^{16}$ In order to identify specific G-protein that could bind to hBLT2, the affunity of hBLT2 to various $\mathrm{G} \alpha$ proteins was measured. since the $\mathrm{G} \alpha$ subunit of heterotrimeric G-protein mainly contributes its interactive effect via GPCR ${ }^{2+.76}$ Also, the cy toplasnic loop regions of GPCR comecting the transmembrane helices or the $\mathrm{C}$-terminus tail

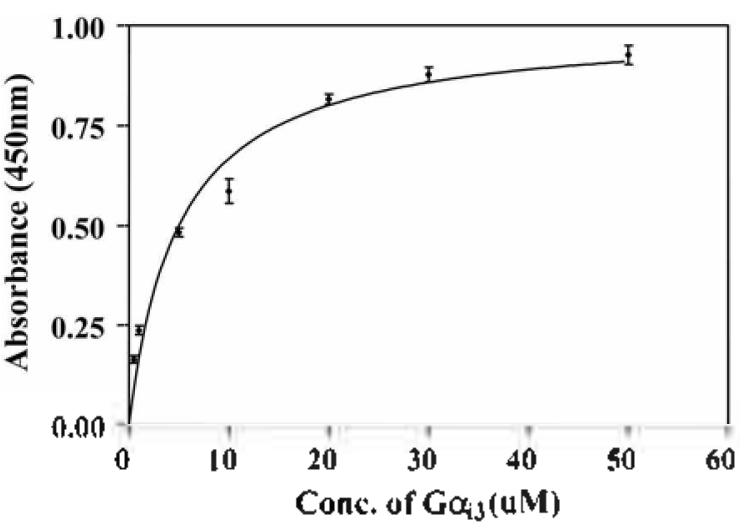

Figure 4. A dose-dependent binding curve of $\mathrm{G} \alpha \mathrm{x}^{3}$ to the immobilized GST-iL 3 BLt? was measured using anti-His tag antibody, and the $\mathrm{K}_{\mathrm{D}}$ value was obtained from a nonlinear regression fitting of the hyperbola function using SigmaPlot version 9.

region could interact with G-proteins. To identify the critical region(s) of hBLT2 for the interaction with $\mathrm{G} \alpha \mathrm{i} 3$, the binding affinities of the cytoplasmic regions of hBLT2 to Gci3 were examined using GST-iL2 ELT2, GST-iL3 BLT2 $_{2}$ or

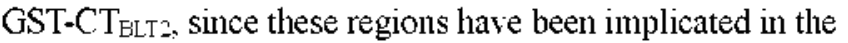
signaling pathway of GPCRs. ${ }^{23.27}$ The relative binding affinities of various $\mathrm{G} \alpha$ proteins were compared by measuring the amount of FITC-labeled $\mathrm{G} \alpha$ proteins which bound to the GST fusion proteins. As shown in Figure 3A. GST-iL3 BLT2 strongly binds to $\mathrm{G} \alpha \mathrm{i} 3$. Also $\mathrm{G} \alpha z$ showed marginal binding

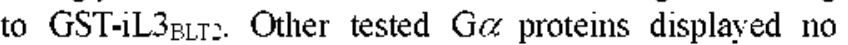
significant binding to the GST-iL3 3 BLT2. On the contrary, GST-iL2ELT2 and GST-CTELT2 could not bind to the $\mathrm{G} \alpha$ proteins (Fig. 3B. C). The binding kinetics of FITC-labeled Gci3 to GST-iL3 $3_{\text {BLT }}$ was further examined by measuring the bound amount of $\mathrm{G} \alpha \mathrm{i} 3$ at different concentrations. and the apparent dissociation constant $\left(\mathrm{K}_{\mathrm{D}}\right)$ of FITC-labeled

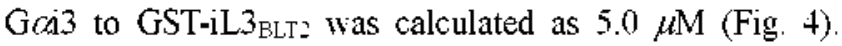
These results indicate that $\mathrm{G} c \mathrm{~s} 3$ has the highest binding affinity to hBLT2 among the $\mathrm{G} \alpha$ proteins of the Gi family, and $\mathrm{Gi} 3$ might be responsible for the signaling of hBLT 2 that induces PT-sensitive chemotactic movement. ${ }^{16}$

\section{Discussion}

The characterization of the interaction between hBLT2 and $\mathrm{G} \alpha$ proteins has been reported in this study. Multiple $\mathrm{G}$ proteins had been implicated in the mediation of the signaling of hBLT2. Activation of cells expressing hBLT2 by LTB4 induced an increase of cellular calcium concentration. and a reduction of cAMP as well as the chemotactic response. imply ing that $\mathrm{G}$-proteins which belong to the $\mathrm{Gi}$ or Gq families might interact with hBLT $2 .^{16}$ These responses were interfered with the treatment of PT. In particular, hBLT2-mediated chemotactic response was completely blocked by PT. ${ }^{16}$ Since PT modifies $\mathrm{G} \alpha$ subunits of Gi families, a member of Gi family is assumed to mediate hBLT2-mediated chemotactic response. As shown in Figure 3. Goi3 showed the highest binding to the intracellular loop 
regions of $h B L T 2$ among the three tested $G c a$ subunits. suggesting that $\mathrm{G} \alpha \mathrm{i} 3$ is a potential candidate for mediating the LTB4-dependent chemotactic response in cells expressing hBLT2. The wide distribution of Gi3 and hBLT2 in various types of tissues also supports the involvement of $\mathrm{Gi3}$ in the signaling of hBLT2. ${ }^{16,25}$ Also, the importance of the iL 3 region of $h B L T 2$ for the interaction with $\mathrm{G} \alpha \mathrm{i} 3$ was demonstrated in this study. Involvement of the iL 3 region as a major contributor for the interaction with G-protein had been reported in other GPCRs. Mutation in the iL3 region abolished proper signaling of the $\beta$-adrenergic receptor ${ }^{29}$ or serotonin receptor $5-\mathrm{HT}_{2 \mathrm{~A}},{ }^{3 \mathrm{ij}}$ Of note, $\mathrm{G}$ os I bound specifically to the iL 3 of serotonin receptor type 6 , and the single amino acid substitutions impaired signaling efficiency of the receptor ${ }^{-3}$ Aunong the tested GST-fusion proteins, GSTiL $3_{\text {BLT: }}$ exhibited strong binding to $\mathrm{G} \alpha \mathrm{i} 3$ (Fig. 3), whereas the GST-IL2 $2_{\text {BLT: and GST-CT }}$ BLT: failed to display any detectable association with the $\mathrm{G} \alpha$ subunits. indicating that the iL2 or CT region of hBLT2 might be involved in the signaling process either by interacting with $\mathrm{G} \beta$ or $\mathrm{G} \gamma$ subunits or mediating receptor recycling rather than by direct interaction with $\mathrm{G} \alpha \mathrm{i} 3$

The binding affinity between Goi3 and GST-iL $3_{\text {BLT:_-_with }}$ $K_{D}$ value of $5.0 \times 10^{-6} \mathrm{M}$ ) was substantially lower than the affinity of the refolded BLTI for heterotrimeric G-proteins with a $\mathrm{K}_{\mathrm{D}}$ value of $7.8 \times 10^{-8} \mathrm{M}^{31}$ suggesting that the affinity of the hBLT2 to the heterotrimeric G-protein would probably be higher than the affinity to the isolated $\mathrm{G} \alpha \mathrm{i} 3$ subunit, and the $\mathrm{G} \beta \gamma$ subunits may be involved in the interaction with iL 3 or other cytoplasmic regions of hBLT2. Further study on the ligand-induced conformational change of hBLT2 and its interaction with the Gi3 protein should reveal the signaling mechanism of hBLT2.

Acknowledgements. We thank to Dr. Jae-Hong Kim of Korea University for providing the human BLT2 cDNA. This work was supported by grants from the $21 \mathrm{C}$ Frontier Research Program, Functional Proteomics Research (FPR05B2040), Ministry of Science and Technology, Korea.

\section{References}

1. Serhan. C. N.: Haeggstrom. J. Z.: Leslie. C. C. FASEB J. 1996. 10. $1147-1158$

2. Ford-Hutchinson. A. W: Bray, M. A: Doig. M. V: Shipley. M. E.: Smith. M. Nature 1990, 286. 264-265.

3. Ng. C. F.: Sun. F. F.: Taylor. B. M.: Wolin. M. S.: Wong. P. Y. K. J. Inminol. 1991. H77, 3096-3103.

4. Huang. W. W.: Garcia-Zepeda. E. A.: Sauty. A.: Oettgen. H. C.: Rothenberg. M. E.: Luster. A. D. J. Exp. Med. 1998. 188. 10631074

5. Chen, X. S: Sheller. J. R: Johnson. E. N.: Funk; C. D. Nature 1994. 372. 179-182.
6. Goulet. T. L.: Snouwaert. J. N.: Latour. A. M.: Coftiman. T. M. Koller. B. H. Proc. Kall Acad. Sci. USA 1994. 91. 12852-12856.

7. Griffiths. R. J.: Pettipher. E. R.: Koch. K.: Farrell. C. A.: Breslow R.: Conklyn. M. J.: Smith. M. A.: Hackman, B. C.: Wimberly, D. J:- Milici. A. J.: Scampoli. D. N.: Cheng, J. B.: Pillar. J. S. Pazoles, C. J : Liston. T. E; Showell, H. J. Proc. Natl Acad Sci. USA 1995. $92.517-521$

8. Tumer. C. R.: Breslow. R.: Conklyn. M. T.: Andresen. C. J.: Patterson. D. K.: Lopez-Anaya. A.: Owens. B.: Lee. P.: Watson. J W.: Showell. H. J. J. Chin. Ihest. 1996. 97, $381-387$.

9. Sharon, P.: Stenson, M. F. Gastroenterolog, 1984. 86, 453-460.

10. Griffiths. R. J.; Smith, M. A; Roach. M. L.; Stock, J. L.; Stam. E J.: Milici. A. J.: Scampoli. D. N.: Eskra. T. D.: Byrum. R. S.: Koller. B. H.: MeNeish. I. D. J. Exp. Hed 1997. 185. 1123 1129.

11. Jackson, W. T.: Froelich. L. L.: Boyd. R. J: Schrementi, J. P: Saussy, D. L. Jr.: Schultz, R. M. Sawyer, J. S.: Sofia. M. J.; Herron. D. K: Goodson. T.. Jr.: Snyder, D. W. Pechous. P. A.; Spaethe. S. M.: Romant. C. R.: Fleisch. T. H. J. Phormacol Exp. Ther: 1999. 288. 286-294

12. Showell. H. J.: Conklyt1. M. J.: Alpert. R.: Hingorani. G. P.: Wright. K. F; Smith. M. A.; Stam, E; Salter. E. D.: Scampoli, D N.; Meltzer, S.; Reiter, L. A.: Koch. K.: Piscopio, A. D.: Cortina. S. R.: Lopez-Anaya. A.: Pettipher, E. R.: Milici, A. J:- Griffiths, R. J. J. Pharmacol. Exp. Thet 1998. 285.946-954.

13. Kishikawa. K.: Tateishi. N.: Maruyama. T.: Seo. R.: Toda. M.: Miyamoto. I. Prostaglandins 1992. 4+2.261-275.

14. Tager, A. M.; Luster. A. D. Prost. Leuko. Ess. Fattu Acids 2003. 69. $123-134$

15. Truselius. Y.: Nilsson. N. E.; Kotarshy, K.: Olde. B.; Owman. C. Biochent Biophns. Res Contm 2000. 274. 377-382.

16. Yokomizo. T: Kato. K.: Terawaki. K.: Izumi. T.: Shimizu. T. J Exp. Hed. 2000. 192.421-431

17. Yohomizo. T: Kato, K.: Hagiya. H: Tizumi, T.: Shimizu. T. $d$. Biol. Chem. 2001, 276. 12454-12459

18. Yokomizo. T.: Izumi, T.: Chang, K.: Takuwa. Y.: Shimizu, T Nature 1997.387. 620)-624

19. Yoo. M. H.: Sontg. H.: Woo. C. H.: Kim. H.: Kim. I. H. Oncogene 2004. 23. $9259-9268$

20. Tong, W. G.: Ding, X. A.: Henning, R, Witt. R. C: Standop, J.; Pour. P. M.: Adrian. T. E. Clic. Cancer Res. 2002, 8, 3232-3242.

21. Powell, W. S.; Macleod, R. J.: Gravel. S.; Gravelle, F; Bhakar. A J. Imminol. 1996. 156.336-342

22. Gaudreau, R.: Le Gouill. C.: Metaoui. S.: Lemire. S.: Stankova. T.: Rola-Pleszczynski. M. Biochem. J. 1998. 335. 15-18.

23. Kang. H.; Lee, W. K.; Choi. Y. H.: Vukoti, K. M.: Bang. W. G: Yu. Y. G. Biochem. Biophus. Res. Comm. 2005, 329. 684-692.

24. Hamm. H. E.: Deretic, D.; Arendt, A.: Hargrave, P. A.: Koenig. B.: Hofmann. K. P. Science 1988. 241. 832-835.

25. Kisseley. O. G.: Kao. T.: Ponder. T. W.: Fann1. Y. C.: Gautann. N.: Marshall. G. R. Proc Natl Acad Sci LSA 1998. $95.4270-4275$.

26. Itoh. Y.: Cai. K.; Khorana. H. G. Froc. Natl Acad Sci. LSt 2001 98. $4883-4887$.

27. Savarese, T. M.; Fraserm. C. M. Biochem. J. 1992. 283. 1-19

28. Garibay. T. L.: Kozasa. T.: Itoh. H.: Tsukamoto. T.: Matsuoka. M. Kaziro. Y. Biochim. Biophns .1cta 1991. 1094. 192-199.

29. Kjelsberg. M. A.: Cotecchia. S.: Ostrowski. T.: Caron. M. G: Lefkowitz, R. J. J. Biol. Chom 1992. 267, 1430-1433.

30. Egan. C. T.; Herrick-Davis, K.: Teitler, M. J. Pharmacol Exp. Ther: 1998, 286, 85-90.

31. Baneres. T. L.: Parello. J. J. Mol Biol 2003. 329. 815-829 